Çağlar, M. Ç ve Canbulat, M. (2021). Türkçe öğretim programının ve Türkçe ders kitabının dilbilim açısından incelenmesi. Ana Dili Eğitimi Dergisi, 9(1), 210-224.

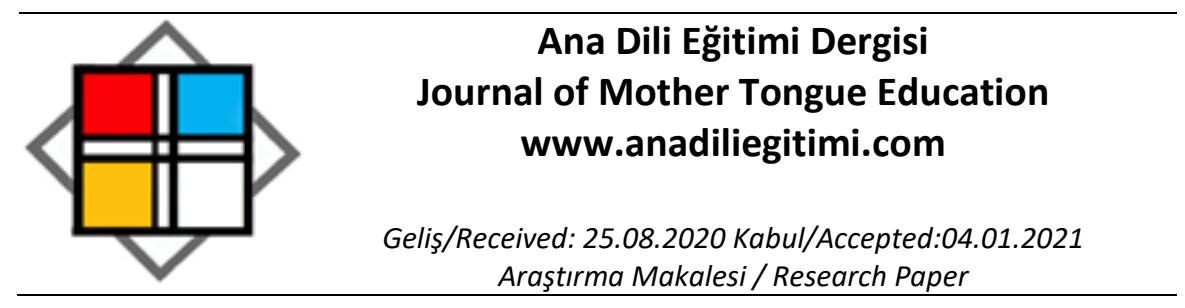

\title{
Türkçe Öğretim Programının ve Türkçe Ders Kitabının Dilbilim Açısından İncelenmesi*
}

\author{
Mustafa Çağrı ÇAĞLAR** \\ Mehmet CANBULAT ${ }^{* * *}$
}

\begin{abstract}
Öz
Bu araştırmanın amacı 2018 Türkçe Dersi Öğretim Programı́nda yer alan 6. sınıf kazanımları ile 6. sınıf Türkçe Ders Kitabı’nda bulunan etkinlikleri dilbilimsel kavramlar bağlamında gruplandırıp incelemektir. Nitel araştırma yaklaşımı ç̧inde yürütülen bu çalışmada 2018 Türkçe Dersi Öğretim Programı ile 2018 yılında MEB Yayınları tarafından basılan Ortaokul ve İmam Hatip Ortaokulu 6. sınıf Türkçe Ders Kitabı örneklem olarak seçilmiştir. Çalışmanın verileri, belge incelemesi yoluyla toplanmıştır. Çalışmada elde edilen verilerin çözümlenmesi sırasında içerik çözümlemesi kullanılmışır. Çalışma sonucunda Türkçe Öğretim Programı ile Türkçe Ders Kitabı'nın büyük ölçüde uyumlu olduğu, programda yer alan kazanımlardaki dilbilimsel arka planın etkinliklere uyumlu bir şekilde yansıtıldığı tespit edilmiştir. Programda ve ders kitabında en çok kazanımın metindilbilimle ilgili olduğu en az kazanımın ise sesbilim ve sözdizim alanında olduğu görülmüştür. Anahtar Kelimeler: Türkçe dersi öğretim programı, Türkçe ders kitabı, dilbilim ve alt alanları.
\end{abstract}

\section{Examination of the Turkish Curriculum and Course Book from the Standpoint of Linguistics}

\begin{abstract}
The purpose of this research is to group and examine the $6^{\text {th }}$ grade learning outcomes in the 2018 Turkish curriculum and the activities in the corresponding Turkish course book in terms of linguistic concepts. The sample in this study, which was carried out in the qualitative research paradigm, consisted of the $6^{\text {th }}$ grade Turkish curriculum of 2018 and the regular middle school and religious middle school Turkish course book published by the MEB Publications in the same year. During the analysis phase of the collected data, document review was used. Content analysis was used during the analysis of the data obtained in the study. The results showed that the Turkish curriculum and the Turkish course book were congruent to a great extent, and that the fundamental linguistic considerations in the learning outcomes of the curriculum were reflected harmoniously in the activities. It was seen that the most gains in the program and the course book were related to text linguistics and the areas in which the least amount of gains were observed were the fields of phonetics and syntax.
\end{abstract}

Keywords: Turkish curriculum, Turkish course book, linguistics and its subfields.

\section{Giriş}

Tüm insanlar yaradılış gereği evrensel olan bir dil yetisi içinde doğar ve içinde bulunduğu toplumun dilini edinir. Birey için bir sonraki süreç ise evrensel olan dil yetisi vasıtasıyla toplumsal olan dil içinde bireysel sözler oluşturabilmektir. Dilin bilinç seviyesinde edinilip öğrenilebilmesinde eğitim

\footnotetext{
${ }^{*}$ Bu makale, birinci yazarın Akdeniz Üniversitesi, Eğitim Bilimleri Enstitüsü tarafından kabul edilmiş yüksek lisans tezinden üretilmiştir.

** Doktora Öğrencisi, Akdeniz Üniversitesi, Eğitim Fakültesi, Türkçe Eğitimi Ana Bilim Dalı, Antalya, caglarmustafacagri@gmail.com, ORCID: 0000-0003-3947-2366

*** Prof. Dr., Akdeniz Üniversitesi, Eğitim Fakültesi, Türkçe Eğitimi Ana Bilim Dalı, Antalya, canbulatm@gmail.com, ORCID: 0000-0002-1781-2684
} 
önemli bir değişkendir. Eğitim için de dil vazgeçilmez bir olgu olma özelliği taşımaktadır. Bu ilişkiden doğan ve bireylerin dil becerilerini geliştirerek onlara etkili bir iletişim olanağı sunan bir süreç şeklinde tanımlanabilen dil eğitimi genelde ana dili eğitimi-öğretim boyutunu kapsamaktadır.

Ana dili eğitimi, Türkçenin ana dili olması sebebiyle öncelikli olarak Türkçe derslerinde verilmektedir. Buna bağlı olarak eğitim sürecinin merkezinde yer alan çok boyutlu bir etkinlik olarak nitelendirebileceğimiz Türkçe eğitiminin öncelikli amaçları; bilimsel veriler ışı̆̆ında bireylere ana dillerinin sınırlarını çizerek dilin sistemini ve işleyişini -dilden hareketle- kavrama fırsatı vermeyi, onların doğru ve düzgün bir şekilde anlayıp anlatarak özgün sözler yaratabilmelerini ve dil konusundaki alışkanlıklarını farkındalıklara dönüştürebilmelerini sağlamaktır. Bu durum Türkçe eğitiminin disiplinler arası çalışmalarla beslenmesini ve hızla bilimselleşmesini zorunlu kılmaktadır. Bu bağlamda öğretim programlarının, ders araç ve gereçlerinin, dört temel dil becerisi ve dilbilgisinin bilimsel temellere dayandırılarak hazırlanması önemli görülmektedir. Çünkü hayatımııın her anına değen dilin, eğitimi ve öğretimi hususunda yanılgılardan olabildiğince uzaklaşabilmenin yolu bilimsel bir yaklaşımı kabullenmekten geçmektedir. Bu durumda Türkçe eğitiminin ilişki kurduğu ilk disiplin şüphesiz inceleme nesnesi dil olan ve dile bilimsel olarak yaklaşan dilbilim ve onun alt alanlarıdır.

Dilbilim; dili oluşturan tüm parçaları işlevsel bir dil sistemi içinde gören, dilin mantığını bu sistemsel bakış açısı ile açıklamaya çalışan ve dili bilimin nesnesi olarak incelemeyi amaç edinen bilimsel bir disiplindir. Bu özelliğiyle dilbilimin dil öğretimine kazandırdığı en köklü değişim, sürece bilimsel bir tutum açısından yaklaşmasıdır. Bilindiği gibi dil öğretiminde bilimsel bir tutumun gereği de araştırmacı ve eleştirel bir bakış açısına sahip olmaktan geçmektedir. Bu bakış açısı beraberinde dili salt bilgi yığını olarak gören kişisel beğeni temelli kuralcılığı yıkarak dil incelemelerine ve dil öğretimine sorgulayıcı, yeni gelişmelere açık, nitelikli, işlevsel ve nesnel bir boyut kazandırmıştır. Kocaman'a (2006, s. 162) göre dilbilim dil öğretimine iki noktada katkı sağlayabilir. Bunlardan ilki dilbilimin öğretilecek dili betimlemesidir. Bir dilin sistemi, yapısı, işleyişi bilinmeden o dilin öğretilmesi beklenemez. Dilbilimin "dile ilişkin kavrayışımızı geliştirerek dil öğreticilerine kimi ipuçları ya da sezdirimler sağlaması" ise ikincil bir katkı olarak söylenebilir. Kısaca çözümlenmiş dilin kuramsal temelini bilmek, dil eğitimcisine uygulama düzleminin her aşamasında rehberlik etmektedir.

Başlangıcından beri “dil öğretimi dilbilimin önemli ilgi alanlarından biri olagelmiştir. Dilbilimin ürünleri, verileri ve katkıları olmadan dil öğretimini düşünmek olanaksız gibidir" (Enginarlar, 2006, s. 151). Bu anlayıştan yola çıkarak dil ve eğitim kavramlarını bilimsellikle buluşturmaya çalışan "eğitimsel dilbilim" dil eğitiminde dilbilimin uygulama alanı olarak tanımlanabilir (İmer, Kocaman ve Özsoy, 2019). Eğitimsel dilbilim bağlamında genel olarak dil eğitimi özel olarak da Türkçe eğitiminin dilbilimin verilerinden yararlanması gerektiği söylenebilir. Çünkü yaşamımızın her aşamasında olan dilin, eğitimi ve öğretimi konusunda yanılgılardan olabildiğince uzak durmanın yolu bilimsel bir bakış açısını kabullenmekten geçmektedir. Bu da ancak dil incelemelerine nesnelliği, sürekli araştırmayı, dizgeli bir yaklaşımı benimseten dilbilimin ürünleri ve katkıları ile mümkün olacaktır. Bu açıklamalardan dil eğitiminin her aşamada sadece dilbilimiyle sınırlı olduğu ve her anlamdaki dilbilim gelişmelerini yakından takip etmek mecburiyetinde kaldığı gibi bir sonuca ulaşılmamalıdır (Börekçi, 2009). Ancak Türkçe eğitimi ile dilbilim arasındaki iletişim de sürekli ve canlı tutulmalı yeri geldiğinde dilbilimin bulguları Türkçe eğitimine ivedilikle aktarılabilmelidir.

Dilbilimsel verilerin dil eğitiminde kullanılması gerekliliği alanyazında birçok araştırmacı tarafından (Kocaman, 1998, 2006; Enginarlar, 2006; Alyaz, 2006; Börekçi, 2009; Kıran ve Kıran, 2013) sıklıkla dile getirilmiş olsa da kuramsal bilgi olarak kalmaktan öteye gidememekte, uygulama düzleminde dilbilimin Türkçe eğitimine yansıtılamadığı düşünülmektedir. Kocaman'a (2009a) göre Türkçe eğitimi sürecinde dilbilimdeki gelişmelerin takibi bir yana, dilbilimin adı bile anılmamaktadır. Sezer'e (1988) göre dilbilimin Türkçe eğitimindeki uygulanabilirliği iç karartıcı bir durumdadır. Börekçi' ye (1997) göre ise Türk dilinin en büyük sorunlarından biri dilbilimin dil öğretimine yansımamış olmasıdır. Tura (1983), İmer (1990), Aydın (1999), Kocaman (1998, 2009b), Aksan (2004), Güneyli ve Küçükavşar (2008, 2011), Çağlayan Dilber (2017), Canbulat, Çağlar ve Güven (2018) gibi pek çok araştırma sonunda ortaya çıkan sonuçlar da bu görüşleri doğrular niteliktedir. 
Belirtilen ifadelerden hareketle araştırmada, 2018 Türkçe Dersi Öğretim Programı́nda (TDÖP) yer alan kazanımları ve 6. Sınıf Türkçe Ders Kitabı'nda yer alan etkinlikleri dilbilimsel kavramlar bağlamında incelemek amaçlanmıştır. Bu bağlamda, 2018 Türkçe Dersi Öğretim Programı 6. sınıf kazanımlarının oluşturulmasında dilbilimin verilerinden ne ölçüde faydalanıldığı, faydalanılmışsa bunun 6. Sınıf Türkçe Ders Kitabı etkinliklerine kavramsal olarak yansıyıp yansımadığı araştırılmaktadır. Bu doğrultuda inceleme şu ulamlar çerçevesinde yapılacaktır:
a) Sesbilim
b) Biçimbilim ve sözdizimi
c) Metindilbilim
d) Anlambilim ve sözcükbilim
e) Göstergebilim

\section{Yöntem}

Bu çalışmanın kapsamını, Türkçe öğretim programları ve Türkçe ders kitapları oluşturmaktadır. 2018 Türkçe Dersi Öğretim Programı ile 2018 yılında MEB Yayınları tarafından basılan Ortaokul ve İmam Hatip Ortaokulu 6. Sınıf Türkçe Ders Kitabı araştırmanın örneklemi olarak seçilmiştir. Araştırma, belge inceleme yöntemiyle yapılmış bir içerik çözümleme çalışmasıdır. Nitel araştırmada belge inceleme tek başına bir veri toplama yöntemi olabileceği gibi diğer veri toplama yöntemleri ile birlikte de kullanılabilir. Belge inceleme, "araştırılması hedeflenen olgu veya olgular hakkında bilgi içeren yazılı materyallerin analizini kapsar" (Yıldırım ve Şimşek, 2018, s. 189).

Verilerin toplama süreci, araştırma için seçilen 2018 Türkçe Dersi Öğretim Programı ve 6. Sınıf Türkçe Ders Kitabı'nın temini ile başlamıştır. Sonraki aşamada Türkçe Dersi Öğretim Programı'nın 6. sınıf kazanımları uzman eşliğinde incelenmiş ve dilbilimsel içerik taşıyan kazanımlar belirlenmiştir. Belirlenen kazanımlar uzman eşliğinde, dilbilimin alt alanları bağlamında yeniden incelenmiş ve toplanan veriler sesbilim, biçimbilim, sözdizim, sözcükbilim, metindilbilim, anlambilim ve göstergebilim başlıkları altında sınıflandırılmıştır. Belli alanlara göre sınıflandııılan bu kazanımların programda açıklamalarına yer verilip verilmediği de incelenmiş, açıklamaları varsa bunlar da belirtilmiştir. Dilbilimsel kavramlar bağlamında sınıflandırılan ve tablolar halinde sunulan kazanımların Türkçe ders kitabı etkinliklerine kuram ve uygulama boyutunda aktarımı ve işlenişi incelenmiş, aktarımın yapıldığı etkinlikler gruplandırılarak tablolar halinde sunulmuştur. Türkçe ders kitabında anlambilim ve sözcükbilim aynı etkinliklerde yer aldığından çalışmada da bu iki kavram aynı başlık altında incelenmiştir. Göstergebilim alanı ise dil dışı göstergelerle sınırlı tutulmuştur.

Bu araştırmada içerik çözümleme yöntemi kullanılmıştır. İçerik çözümlemesi, benzer verileri belirli kurallara bağı olarak kodlama ve bu kodlamaları anlaşılır bir biçimde düzenleyip yorumlamaya dayalı bir tekniktir (Yıldırım ve Şimşek, 2018).

\section{Bulgular ve Yorum \\ Sesbilimle ilgili Kazanımların 6. Sınıf Türkçe Ders Kitabına Yansıması \\ 2018 TDÖP'de sesbilim ile ilgili herhangi bir kazanıma rastlanmamakla birlikte ders kitabındaki sesbilime ait etkinlikler, Tablo 1'de görülmektedir.}

Tablo 1.

Türkçe Ders Kitabındaki Sesbilimle ilgili Etkinlikler

\begin{tabular}{ll}
\hline Kazanımlar & Etkinlik sayfa numarası \\
\hline Sesbilim & $25-9 / a, 62-6,116-4 / c, d, 261-5 / b$ 268-6/a
\end{tabular}

Tablo 1'de kazanımların sayfaları ile etkinlik numaraları ve bölümleri birlikte verilmiştir. Örnek: 116-4/c, d; 116. Sayfadaki 4. Etkinliğin c ve d bölümlerini işaret etmektedir. Ders kitabında sesbilim alanı ile ilgili toplam 5 etkinliğe yer verildiği görülmektedir. Bu etkinliklerin ağırlık olarak 
şiirdeki ses uyumlarıyla ya da bir metni seslendirmeyle ilgili olduğu görülmüştür. Aşağıda bu etkinliklerden bir örnek sunulmuştur:

\section{Etkinlik A) Aşağıdaki şiiri vurgu ve tonlamalara dikkat ederek okuyunuz.}

\section{Biçimbilim ve Sözdizimiyle Illgili Kazanımların 6. Sınıf Türkçe Ders Kitabına Yansıması}

Türkçe Öğretim Programdaki 6. sınıf kazanımları ve 6. sınıf Türkçe ders kitabındaki etkinlikler incelendiğinde biçimbilim ve sözdizimi ile ilgili kazanımlara aşağıdaki şekliyle yer verildiği görülmektedir:

\section{Biçimbilimle ilgili Kazanımların 6. Sınıf Türkçe Ders Kitabına Yansıması}

Biçimbilimle ilgili kazanımlara Tablo 2'de yer verilmiştir.

Tablo 2.

Öğretim Programındaki Biçimbilimle Illgili Kazanımlar

\begin{tabular}{llll}
\hline Sayı & Beceri Alanı & Kazanım & Açıklama \\
\hline 1 & Okuma & $\begin{array}{l}\text { Çekim eklerinin işlevlerini ayırt eder. (7. } \\
\text { kazanım) }\end{array}$ & $\begin{array}{l}\text { isim çekim ekleri (çoğul eki, hâl } \\
\text { ekleri, iyelik ekleri ve soru eki) } \\
\text { úzerinde durulur. }\end{array}$ \\
\hline 2 & Okuma & $\begin{array}{l}\text { İsim ve sıfatların metnin anlamına olan } \\
\text { katkısını açıklar. (8. kazanım) }\end{array}$ & Açıklama yapılmamıştır. \\
\hline 3 & Okuma & $\begin{array}{l}\text { İsim ve sıfat tamlamalarının metnin } \\
\text { anlamına olan katkısını açıklar. (9. } \\
\text { kazanım) }\end{array}$ & Açıklama yapılmamıştır. \\
\hline 4 & Okuma & $\begin{array}{l}\text { Edat, bağlaç ve ünlemlerin metnin } \\
\text { anlamına olan katkısını açıklar. (10. } \\
\text { kazanım) }\end{array}$ & Açıklama yapılmamıştır. \\
\hline 5 & Okuma & $\begin{array}{l}\text { Basit, türemiş ve birleşik kelimeleri ayırt } \\
\text { eder. (11. kazanım) }\end{array}$ & Açıklama yapılmamıştır. \\
\hline 6 & Okuma & $\begin{array}{l}\text { Zamirlerin metnin anlamına olan katkısını } \\
\text { açıklar. (12. kazanım) }\end{array}$ & Açıklama yapılmamıştır. \\
\hline
\end{tabular}

Tablo 2'de görüldüğü gibi TDÖP incelendiğinde biçimbilim ile ilgili 6 kazanıma yer verildiği görülmektedir. Bu kazanımların tamamının "okuma" beceri alanında verildiği görülmektedir. Öğretim programında, kazanımlardan 5'inin açıklamasına yer verilmediği görülürken yalnız 7. kazanımda açıklamaya yer verildiği görülmektedir.

Biçimbilimle ilgili etkinliklere Tablo 3'te yer verilmiştir.

Tablo 3.

Türkçe Ders Kitabındaki Biçimbilimle Ilgili Etkinlikler

\begin{tabular}{ll}
\hline Kazanımlar & Etkinlik sayfa numarası \\
\hline Sözcük türü & $16-6,36-5,83-6,89-8,95-7,100-7,112-5,117-5 / c, 122-4,128-8,143-6,151-7$, \\
& $210-6 / a, b, 220-7,249-6,261-6$
\end{tabular}


Tablo 3'te Türkçe ders kitabındaki biçimbilimle ilgili 19 etkinliğe yer verildiği görülmektedir. Bu etkinliklerden 16 'sının sözcük türü, 3’ünün ise eklerin öğretimi ile ilgili olduğu görülmektedir. Aşağıda bu etkinliklerden örnekler sunulmuştur:

6. Etkinlik: Aşağıdaki metni inceleyiniz. Metinde alt çizili kelimelerin hangi varlıkların adlarını karşıladığını bulunuz. Varlıkların adlarını ilgili kutuların içine örnekteki gibi yazınız.

6. Etkinlik: Aşağıdaki görsellerde yer alan kelimelerle ekleri örnekteki gibi birleştiriniz. Anlamının değiştiğini düşündüğünüz kelimeleri yuvarlak içine alınız.

\section{Sözdizimiyle Ilgili Kazanımların 6. Sınıf Türkçe Ders Kitabına Yansıması}

Sözdizimiyle ilgili kazanımlara Tablo 4'te yer verilmiştir.

Tablo 4.

Öğretim Programındaki Sözdizimiyle ilgili Kazanımlar

\begin{tabular}{|c|c|c|c|}
\hline Sayı & Beceri Alanı & Kazanım & Açıklama \\
\hline 1 & Konuşma & $\begin{array}{l}\text { Konuşmalarında uygun geçiş ve bağlantı } \\
\text { ifadelerini kullanır. (6. kazanım) }\end{array}$ & $\begin{array}{l}\text { Ama, fakat, ancak, lakin, } \\
\text { bununla birlikte ve buna } \\
\text { rağmen ifadelerini kullanmaları } \\
\text { sağlanır. }\end{array}$ \\
\hline 2 & Yazma & $\begin{array}{l}\text { Yazılarında uygun geçiş ve bağlantı ifadelerini } \\
\text { kullanır. (9. kazanım) }\end{array}$ & $\begin{array}{l}\text { Ama, fakat, ancak, lakin, } \\
\text { bununla birlikte ve buna } \\
\text { rağmen ifadelerinin } \\
\text { kullanılması sağlanır. }\end{array}$ \\
\hline 3 & Yazma & Yazdıklarını düzenler. (10. kazanım) & $\begin{array}{l}\text { a) Anlam bütünlüğünü bozan } \\
\text { ifadelerin belirlenmesi ve } \\
\text { düzeltilmesi sağlanır, kavramsal } \\
\text { olarak anlatım bozukluğu } \\
\text { konusuna değinilmez. } \\
\text { b) Metinde yer alan yazım ve } \\
\text { noktalama kuralları ile sınırlı } \\
\text { tutulur. }\end{array}$ \\
\hline
\end{tabular}

Tablo 4'te görüldüğü gibi Türkçe öğretim programı incelendiğinde sözdizimi ile ilgili 3 kazanıma ve bu kazanımların açıklamalarına yer verildiği görülmektedir. Bu kazanımlardan ikisinin yazma becerisi alanında diğerinin ise konuşma becerisi alanında verildiği görülmektedir.

Sözdizimiyle ilgili etkinliklere Tablo 5'te yer verilmiştir.

Tablo 5.

Türkçe Ders Kitabındaki Sözdizimiyle ilgili Etkinlikler

\begin{tabular}{ll}
\hline Kazanımlar & Etkinlik sayfa numarası \\
\hline Sözdizimi & $15-5,54-6 / b, 83-5,190-6 / b, 195-5 / b$
\end{tabular}

Tablo 5'te görüldüğü gibi ders kitabında sözdizimine ilişkin toplam 5 etkinliğin olduğu görülmektedir. Bu etkinliklerin ağırlıklı olarak bağlamdan hareketle cümle tamamlama ile ilgili olduğu görülmüştür. Aşağıda bu etkinliklerden bir örnek sunulmuştur: 
Metindilbilimle İgili Kazanımların 6. Sınıf Türkçe Ders Kitabına Yansıması

Metindilbilimle ilgili kazanımlara Tablo 6'da yer verilmiştir.

Tablo 6.

Öğretim Programındaki Metindilbilimle Ilgili Kazanımlar

\begin{tabular}{|c|c|c|c|}
\hline Sayı & Beceri Alanı & Kazanım & Açıklama \\
\hline 1 & Dinleme/İzleme & $\begin{array}{l}\text { Dinlediklerinde/izlediklerinde geçen } \\
\text { olayların gelişimi ve sonucu hakkında } \\
\text { tahminde bulunur. (1. kazanım) }\end{array}$ & Açıklama yapılmamıştır. \\
\hline 2 & Dinleme/İzleme & $\begin{array}{l}\text { Dinlediklerini/izlediklerini özetler. (3. } \\
\text { kazanım) }\end{array}$ & Açıklama yapılmamıştır. \\
\hline 3 & Dinleme/İzleme & $\begin{array}{l}\text { Dinlediklerinin/izlediklerinin konusunu } \\
\text { belirler. ( } 5 . \text { kazanım) }\end{array}$ & Açıklama yapılmamıştır. \\
\hline 4 & Dinleme/İzleme & $\begin{array}{l}\text { Dinlediklerinin/izlediklerinin ana } \\
\text { fikrini/ana duygusunu tespit eder. ( } 6 . \\
\text { kazanım) }\end{array}$ & Açıklama yapılmamıştır. \\
\hline 5 & Dinleme/İzleme & $\begin{array}{l}\text { Dinlediklerine/izlediklerine yönelik farklı } \\
\text { başlıklar önerir. (7. kazanım) }\end{array}$ & Açıklama yapılmamıştır. \\
\hline 6 & Dinleme/İzleme & $\begin{array}{l}\text { Dinlediklerinin/izlediklerinin içeriğini } \\
\text { değerlendirir. (10. kazanım) }\end{array}$ & $\begin{array}{l}\text { a) Öğrencilere reklam filmleri } \\
\text { dinletilerek/izletilerek bunlardaki } \\
\text { mesajların ve örtülü anlamların } \\
\text { tespit edilmesine yönelik } \\
\text { çalışmalar yaptırılır. } \\
\text { b) Öğrencilerin içeriklerdeki } \\
\text { tutarlıı̆ı sorgulamaları sağlanır. }\end{array}$ \\
\hline 7 & Okuma & $\begin{array}{l}\text { Metni, türün özelliklerine uygun biçimde } \\
\text { okur. (2. kazanım) }\end{array}$ & $\begin{array}{l}\text { Öğrencilerin seviyelerine uygun, } \\
\text { edebî değeri olan şiirleri ve kısa } \\
\text { yazıları türünün özelliğine göre } \\
\text { okumaları ve ezberlemeleri } \\
\text { sağlanır. }\end{array}$ \\
\hline 8 & Okuma & Okuduklarını özetler. (16. kazanım) & Açıklama yapılmamıştır. \\
\hline 9 & Okuma & $\begin{array}{l}\text { Metinle ilgili soruları cevaplar. (17. } \\
\text { kazanım) }\end{array}$ & $\begin{array}{l}\text { Metin içi ve metin dışı anlam } \\
\text { ilişkileri kurulur. }\end{array}$ \\
\hline 10 & Okuma & Metnin konusunu belirler. (19. kazanım) & Açıklama yapılmamıştır. \\
\hline 11 & Okuma & $\begin{array}{l}\text { Metnin ana fikrini/ana duygusunu } \\
\text { belirler. (20. kazanım) }\end{array}$ & Açıklama yapılmamıştır. \\
\hline 12 & Okuma & $\begin{array}{l}\text { Metnin içeriğine uygun başlık belirler. } \\
\text { (21. kazanım) }\end{array}$ & Açıklama yapılmamıştır. \\
\hline 13 & Okuma & $\begin{array}{l}\text { Metindeki hikâye unsurlarını belirler. ( } 22 \text {. } \\
\text { kazanım) }\end{array}$ & $\begin{array}{l}\text { Olay örgüsü, mekân, zaman, } \\
\text { şahıs ve varlık kadrosu, anlatıcı } \\
\text { üzerinde durulur. }\end{array}$ \\
\hline 14 & Okuma & Metnin içeriğini yorumlar. (24. kazanım) & $\begin{array}{l}\text { a) Yazarın olaylara bakış açısının } \\
\text { tespit edilmesi sağlanır. } \\
\text { b) Metindeki öznel ve nesnel } \\
\text { yaklaşımların tespit edilmesi } \\
\text { sağlanır. } \\
\text { c) Metindeki örnek ve ayrıntılara } \\
\text { atıf yapılması sağlanır. }\end{array}$ \\
\hline 15 & Okuma & $\begin{array}{l}\text { Metinler arasında karşılaştırma yapar. } \\
\text { (25. kazanım) }\end{array}$ & $\begin{array}{l}\text { Metinlerin tema, konu, olay } \\
\text { örgüsü ve karakterler açısından } \\
\text { karşılaştırılması sağlanır. }\end{array}$ \\
\hline 16 & Okuma & Metin türlerini ayırt eder. (26. kazanım) & $\begin{array}{l}\text { a) Anı, mektup, tiyatro, gezi yazısı } \\
\text { türleri öğretilmelidir. } \\
\text { b) Metin türlerine ilişkin ayrıntılı }\end{array}$ \\
\hline
\end{tabular}




\begin{tabular}{|c|c|c|c|}
\hline & & & bilgi verilmemelidir. \\
\hline 17 & Okuma & $\begin{array}{l}\text { Metindeki gerçek ve kurgusal unsurları } \\
\text { ayırt eder. (28. kazanım) }\end{array}$ & Açıklama yapılmamıştır. \\
\hline 18 & Yazma & Şiir yazar. (1. kazanım) & Açıklama yapılmamıştır. \\
\hline 19 & Yazma & Bilgilendirici metin yazar. (2. kazanım) & $\begin{array}{l}\text { a) Öğrencilerin konu ve ana fikri } \\
\text { belirlemeleri, buna göre giriş, } \\
\text { gelişme, sonuç bölümlerinde } \\
\text { yazacaklarının taslağını } \\
\text { oluşturmaları ve ilk paragrafta } \\
\text { amaçlarını ifade etmeleri } \\
\text { sağlanır. } \\
\text { b) Öğrenciler yazılarında günlük } \\
\text { hayattan örnekler vermeleri için } \\
\text { teşvik edilir. }\end{array}$ \\
\hline 20 & Yazma & Hikâye edici metin yazar. (3. kazanım) & $\begin{array}{l}\text { a) Öğrencilerin zaman, mekân, } \\
\text { şahıs ve olay unsurlarını } \\
\text { belirlemeleri, hikâyenin serim, } \\
\text { düğüm ve çözüm bölümlerinde } \\
\text { anlatacaklarının taslağını } \\
\text { oluşturmaları sağlanır. } \\
\text { b) Öğrenciler yazım kılavuzundan } \\
\text { yararlanmaları ve yeni öğrendiği } \\
\text { kelimeleri kullanmaları için teşvik } \\
\text { edilir. }\end{array}$ \\
\hline 21 & Yazma & $\begin{array}{l}\text { Bir işi işlem basamaklarına göre yazar. ( } 6 \text {. } \\
\text { kazanım) }\end{array}$ & Açıklama yapılmamıştır. \\
\hline 22 & Yazma & $\begin{array}{l}\text { Yazdıklarının içeriğine uygun başlık } \\
\text { belirler. (8. kazanım) }\end{array}$ & Açıklama yapılmamıştır. \\
\hline 23 & Yazma & Kısa metinler yazar. (14. kazanım) & $\begin{array}{l}\text { Duyuru, ilan ve reklam metinleri } \\
\text { yazdırılır. }\end{array}$ \\
\hline
\end{tabular}

Tablo 6'da görüldüğü gibi Türkçe öğretim programı incelendiğinde metindilbilim ile ilgili 23 kazanıma yer verildiği görülmektedir. Bu kazanımlardan altısının dinleme/izleme becerisi, 11 kazanımın okuma ve 6 kazanımın yazma becerisi alanında verildiği görülmektedir. Programda dinleme/izleme becerisi alanında 1 , okuma becerisi alanında 6 , yazma becerisi alanında ise 3 kazanımın açıklamalarının yapıldığı görülmektedir.

Metindilbilimle ilgili etkinliklere Tablo 7'de yer verilmiştir.

Tablo 7.

Türkçe Ders Kitabındaki Metindilbilimle Ilgili Etkinlikler

\begin{tabular}{ll}
\hline Kazanımlar & Etkinlik sayfa numarası \\
\hline Metindilbilim & $14-2,17-8 / \mathrm{c}, 20-3,21-4 / \mathrm{a}, 23-6,23-7,24-8,25-9 / \mathrm{b}, 28-2,29-4,30-6,31-7,34-2$, \\
& $34-3,37-7 / \mathrm{a}, 47-2,47-3,48-4,52-1 / \mathrm{b}, 52-2,53-4,58-2,61-5 / \mathrm{b}, 64-2,65-4 / \mathrm{b}, \mathrm{c}$, \\
& $\mathrm{d}, 66-6,80-2,81-3,82-4,86-2,88-5,88-6,92-2,93-3,93-4,94-5,94,6 / \mathrm{c}, 97-2$, \\
& $97-3,98-4,98-5,99-6,101-8,110-2,111-3,115-2,116-4 / \mathrm{a}, \mathrm{b}, 117-5 / \mathrm{a}, \mathrm{b}, 120-2$, \\
& 121-3/b, c, 122-3/b, c, 125-2, 126-3, 126-4, 126-5, 129-10, 139-2, 139-3, 140- \\
& 4/b, d, 142-5, 146-2, 148-5, 150-6, 154-1/b, c, 154-2, 157-5, 158-6, 158-7, 160- \\
& 1, 161-3, 161-4, 162-6, 174-2, 175-3, 175-4, 177-6, 182-2, 183-4, 184-5, 188-2, \\
& 188-3, 189-5, 190-6/c, 193-2, 194-3, 195-5, 208-2, 209-3, 210-6/c, 210-5, 212-7, \\
& 213-8/b, 216-2, 217-3, 218-4/b, 219-6/b, c, d, 221-8, 224-2, 225-4, 226/5b 227- \\
& 7, 229-9, 231-2, 231-3, 233-5, 234-6, 235-7, 247-2, 247-3, 249-7, 253-2, 254-3, \\
& $254-4,255-6,256-8,259-2,260-3,261-5 / a, 263-8,266-3,267-4,267-5,268-7$, \\
& $268-8 / \mathrm{b}$
\end{tabular}


Tablo 7'de görüldüğü gibi ders kitabında metindilbilime ilişkin toplam 124 etkinliğin bulunduğu görülmektedir. Bu etkinliklerin ağırlıklı olarak metin oluşturma ve metin çözümleme ile ilgili olduğu görülmüştür. Aşağıda bu etkinliklerden örnekler sunulmuştur:

\section{Etkinlik: Aşağıdaki soruları okuduğunuz metinden hareketle cevaplayınız.}

\section{Etkinlik: Aşağıdaki hikâye unsurlarını kullanarak hikâye edici bir metin yazınız.}

4. Etkinlik A) Aşağıda verilen bilgilerden hangileri "Yaşlı Nine" metninin tür özelliklerine uygundur? Yanına çarpı $(\mathrm{X})$ işareti koyarak belirtiniz.

\section{Anlambilim/Sözcükbilimle ilgili Kazanımların 6. Sınıf Türkçe Ders Kitabına Yansıması}

Anlambilim ve Sözcükbilimle ilgili kazanımlara Tablo 8'de yer verilmiştir.

Tablo 8.

Öğretim Programındaki Anlambilim ve Sözcükbilimle Ilgili Kazanımlar

\begin{tabular}{|c|c|c|c|}
\hline Sayı & Beceri Alanı & Kazanım & Açıklama \\
\hline 1 & Dinleme/izleme & $\begin{array}{l}\text { Dinlediklerinde izlediklerinde geçen, } \\
\text { bilmediği kelimelerin anlamını tahmin eder. } \\
\text { (2. kazanım) }\end{array}$ & $\begin{array}{l}\text { Öğrencilerin tahminlerini } \\
\text { kelimelerin sözlük anlamları ile } \\
\text { karşılaşırımaları sağlanır. }\end{array}$ \\
\hline 2 & Konuşma & $\begin{array}{l}\text { Kelimeleri anlamlarına uygun kullanır. (5. } \\
\text { kazanım) }\end{array}$ & $\begin{array}{l}\text { Açıklama } \\
\text { yapılmamıştır. }\end{array}$ \\
\hline 3 & Konuşma & $\begin{array}{l}\text { Konuşmalarında yabancı dillerden alınmış, } \\
\text { dilimize henüz yerleşmemiş kelimelerin } \\
\text { Türkçelerini kullanır. (7. kazanım) }\end{array}$ & $\begin{array}{l}\text { Açıklama } \\
\text { yapılmamıştır. }\end{array}$ \\
\hline 4 & Okuma & $\begin{array}{l}\text { Bağlamdan yararlanarak bilmediği kelime ve } \\
\text { kelime gruplarının anlamını tahmin eder. ( } 5 \text {. } \\
\text { kazanım) }\end{array}$ & $\begin{array}{l}\text { a) Öğrencilerin tahmin ettikleri } \\
\text { kelime ve kelime gruplarını } \\
\text { öğrenmek için sözlük, } \\
\text { atasözleri ve deyimler sözlüğü } \\
\text { vb. araçları kullanmaları } \\
\text { sağlanır. } \\
\text { b) Öğrencinin öğrendiği kelime } \\
\text { ve kelime gruplarından sözlük } \\
\text { oluşturması teşvik edilir. }\end{array}$ \\
\hline 5 & Okuma & $\begin{array}{l}\text { Deyim ve atasözlerinin metne katkısını } \\
\text { belirler. (6.kazanım) }\end{array}$ & $\begin{array}{l}\text { Açıklama } \\
\text { yapılmamıştır. }\end{array}$ \\
\hline 6 & Okuma & $\begin{array}{l}\text { Metni oluşturan unsurlar arasındaki geçiş ve } \\
\text { bağlantı ifadelerinin anlama olan katkısını } \\
\text { değerlendirir. (13.kazanım) }\end{array}$ & $\begin{array}{l}\text { Ama, fakat, ancak, lakin, } \\
\text { bununla birlikte ve buna } \\
\text { rağmen ifadeleri üzerinde } \\
\text { durulur. }\end{array}$ \\
\hline 7 & Okuma & $\begin{array}{l}\text { Metindeki söz sanatlarını tespit eder. } \\
\text { (14.kazanım) }\end{array}$ & $\begin{array}{l}\text { Konuşturma (intak) ve karşıtlık } \\
\text { (tezat) söz sanatları verilir. }\end{array}$ \\
\hline 8 & Yazma & $\begin{array}{l}\text { Yazılarını zenginleştirmek için atasözleri, } \\
\text { deyimler ve özdeyişler kullanır. (7.kazanım) }\end{array}$ & $\begin{array}{l}\text { Açıklama } \\
\text { yapılmamıştır. }\end{array}$ \\
\hline 9 & Yazma & $\begin{array}{l}\text { Yazdıklarında yabancı dillerden alınmış, } \\
\text { dilimize henüz yerleşmemiş kelimelerin } \\
\text { Türkçelerini kullanır. (12. kazanım) }\end{array}$ & $\begin{array}{l}\text { Açıklama } \\
\text { yapılmamıştır. }\end{array}$ \\
\hline
\end{tabular}


Tablo 8'de görüldüğü gibi TDÖP incelendiğinde anlambilim/sözcükbilim ile ilgili 9 kazanıma yer verildiği görülmektedir. Bu kazanımlardan birinin dinleme/izleme becerisi, 2 kazanımın konuşma, 4 kazanımın okuma ve 2 kazanımın yazma becerisi alanında verildiği görülmektedir. Programda 4 kazanıma ilişkin açıklamaların da yapıldığı görülmektedir.

Türkçe ders kitabında anlambilim/sözcükbilim aynı etkinliklerde yer aldığından çalışmada da bu iki kavram aynı başlık altında incelenecektir.

Anlambilim ve Sözcükbilimle ilgili etkinliklere Tablo 9' da yer verilmiştir.

Tablo 9.

Türkçe Ders Kitabındaki Anlambilim ve Sözcükbilimle Ilgili Etkinlikler

\begin{tabular}{ll}
\hline Kazanımlar & Etkinlik sayfa numarası \\
\hline Kelime ve kelime gruplarının & $14-1,20-1,20-2,21-4$, b, 22-5, 28-1,46-1, 52-1/a, 58-1, 64-1, 80-1, \\
öğretimi & $86-1,92-1,97-1,110-1,115-1,120-1,138-1,146-1,154-1 / a, 159-$ \\
& $8,161-2,163-7,174-1,182-1,188-1,193-1,207-1,216-1,219-5$, \\
& $224-1,231-1,246-1,253-1,259-1,262-7,265-1,266-2$
\end{tabular}

\begin{tabular}{ll}
\hline $\begin{array}{l}\text { Alt anlamlılık/Karşıt } \\
\text { anlamlılık/ Eş anlamlılık }\end{array}$ & $33-1,53-5,60-4,224-3$ \\
\hline Söz sanatları & $17-8 / \mathrm{b}, 67-7$ \\
\hline Anlam bütünlüğü & $16-7,54-6 / a, 125-1$
\end{tabular}

Tablo 9' da görüldüğü gibi ders kitabında anlambilim/sözcükbilime ilişkin toplam 47 etkinliğin yer aldığı görülmektedir. Kelime ve kelime gruplarının öğretimine ilişkin 38, alt anlamlılık, karşıt anlamlılık, eş anlamlılığa ilişkin 4, söz sanatlarına ilişkin 2 ve anlam bütünlüğünü buldurmaya yönelik 3 etkinliğe yer verildiği görülmektedir. Aşağıda bu etkinliklerden örnekler sunulmuştur:

\section{Etkinlik A) Aşağıdaki cümleleri inceleyiniz. Alth çizili sözcüklerin arasında nasıl bir anlam ilişkisi olduğunu açıklayınız.}

1. Etkinlik: Aşağıda, şiirde geçen bazı kelimeler verilmiştir. Metinden hareketle bunların anlamlarını tahmin ediniz. Tahminlerinizin doğruluğunu TDK Türkçe Sözlük'ten kontrol ediniz.

\section{Göstergebilimle İgili Kazanımların 6. Sınıf Türkçe Ders Kitabına Yansıması}

Göstergebilimle ilgili kazanımlara Tablo 10' da yer verilmiştir.

Tablo 10.

Öğretim Programındaki Göstergebilimle Ilgili Kazanımlar

\begin{tabular}{llll}
\hline Sayı & Beceri Alanı & \multicolumn{1}{c}{ Kazanım } & Açıklama \\
\hline 1 & Dinleme/İzleme & $\begin{array}{l}\text { Dinlediği/izlediği hikâye edici metinleri } \\
\text { canlandırır. (8. kazanım) }\end{array}$ & $\begin{array}{l}\text { Açıklama } \\
\text { yapılmamıştır. }\end{array}$ \\
\hline 2 & Dinleme/İzleme & $\begin{array}{l}\text { Konuşmacının sözlü olmayan mesajlarını } \\
\text { kavrar. (9. kazanım) }\end{array}$ & $\begin{array}{l}\text { Açıklama } \\
\text { yapılmamıştır. }\end{array}$ \\
\hline 3 & Konuşma & Konuşmalarında beden dilini etkili bir şekilde & Açıklama \\
& kullanır. (4. kazanım) & yapılmamıştır. \\
\hline 4 & Okuma & Görselden ve başlıktan hareketle okuyacağı & Açıklama \\
& & metnin konusunu tahmin eder. (15. kazanım) & yapılmamıştır. \\
\hline 5 & Okuma & Görsellerle ilgili soruları cevaplar. (30. kazanım) & $\begin{array}{l}\text { a) Öğrencilerin haber } \\
\text { fotoğrafları ve karikatürleri } \\
\text { yorumlayarak görüşlerini } \\
\text { bildirmeleri sağlanır. }\end{array}$ \\
\hline
\end{tabular}




\begin{tabular}{|c|c|c|c|}
\hline & & & $\begin{array}{l}\text { b) Haberi/bilgiyi görsel } \\
\text { yorumcuların nasıl } \\
\text { ilettiklerinin sorgulanması } \\
\text { sağlanır. }\end{array}$ \\
\hline 6 & Okuma & $\begin{array}{l}\text { Grafik, tablo ve çizelgeyle sunulan bilgileri } \\
\text { yorumlar. ( } 35 . \text { kazanım) }\end{array}$ & $\begin{array}{l}\text { Açıklama } \\
\text { yapılmamıştır. }\end{array}$ \\
\hline 7 & Yazma & $\begin{array}{l}\text { Yazdıklarını desteklemek için gerektiğinde } \\
\text { grafik ve tablo kullanır. (5. kazanım) }\end{array}$ & $\begin{array}{l}\text { Açıklama } \\
\text { yapılmamıştır. }\end{array}$ \\
\hline
\end{tabular}

Tablo 10 'da görüldüğü gibi Türkçe öğretim programı incelendiğinde göstergebilim ile ilgili 7 kazanıma yer verildiği görülmektedir. Bu kazanımlardan ikisinin dinleme/izleme becerisi, 1 kazanımın konuşma, 3 kazanımın okuma ve 1 kazanımın yazma becerisi alanında verildiği görülmektedir. Sadece okuma becerisi altında verilen 30'uncu kazanıma ilişkin bir açıklamanın yapıldığı görülmektedir:

Göstergebilimle ilgili etkinliklere Tablo 11 'de yer verilmiştir.

Tablo 11.

Türkçe Ders Kitabındaki Göstergebilimle Ilgili Etkinlikler

\begin{tabular}{ll}
\hline Kazanımlar & Etkinlik sayfa numarası \\
\hline Görselleri yorumlama & $15-3,29-3,35-4,59-3,63-7,89-7,111-4,128-9,155-3 / a, b$, \\
& $178-7,194-4,256-7,260-4$, \\
\hline $\begin{array}{l}\text { Grafik/Tablo/Çizelge/Kroki/Harita } \\
\text { broşür, slogan }\end{array}$ & $\begin{array}{l}30-5,55-7,94-6 / a, 113-6 / a, 148-4,156-4,164-8,197-7,226- \\
5 / a, 228-8,227-6,248-5\end{array}$ \\
\hline $\begin{array}{l}\text { Canlandırma/ beden dili/ sözlü } \\
\text { olmayan mesajlar }\end{array}$ & $49-5,49-6,52-3,64-3,123-6,161-5,182-3,232-4 / b, 247-4$, \\
& $268-6 / c$
\end{tabular}

Tablo 11'de görüldüğü gibi ders kitabında göstergebilime ilişkin toplam 35 etkinliğin yer aldığı görülmektedir. Görselleri yorumlamaya ilişkin 13, grafik/tablo/çizelge/kroki/broşür/slogan/harita okumaya ilişkin 12, canlandırma/ beden dili/ sözlü olmayan mesajlara ilişkin 10 etkinliğin olduğu görülmektedir. Aşağıda bu etkinliklerden örnekler sunulmuştur:

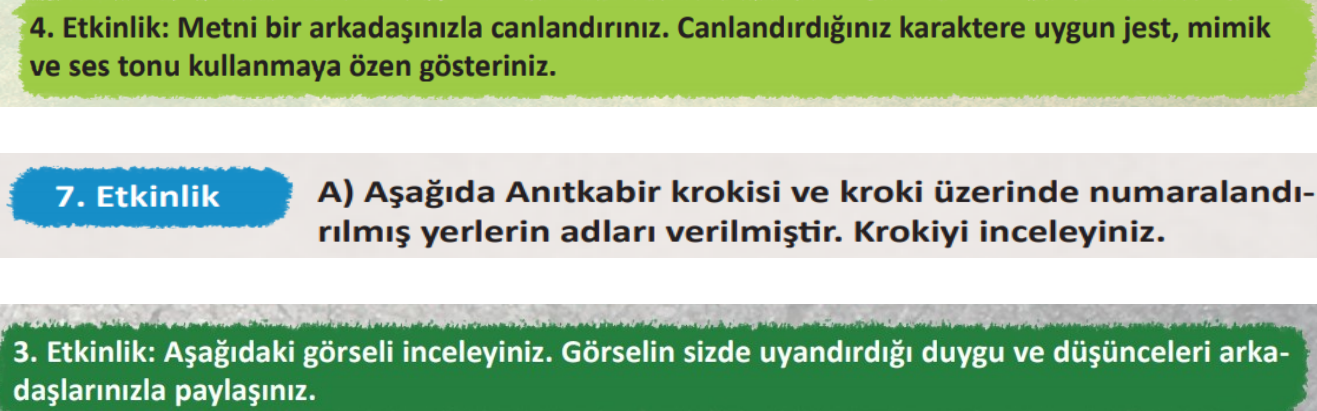

7. Etkinlik A) Aşağıda Anıtkabir krokisi ve kroki üzerinde numaralandırılmış yerlerin adları verilmiştir. Krokiyi inceleyiniz.

3. Etkinlik: Aşağıdaki görseli inceleyiniz. Görselin sizde uyandırdığı duygu ve düşünceleri arkadaşlarınızla paylaşınız.

\section{Sonuç, Tartışma ve Öneriler}

2018 TDÖP ve 6. sınıf Türkçe ders kitabı incelendiğinde vurgu ve tonlamanın Türkçe ders kitabı etkinliklerinde olmasına rağmen öğretim programında olmadığı görülmüştür. Ana dili doğru kullanmanın ve duyguları en iyi şekilde aktarmanın parçalar üstü sesbirimlerinden olan ve anlam ayıran, vurgu ve tonlama ile olduğu düşünülürse vurgu ve tonlamaya ilişkin kazanımlara programda yer verilmemesinin büyük bir eksiklik olacağı düşünülmektedir. Oysa bu kazanımlara 2015 Türkçe Öğretim Programı'nda "Tonlama ve vurgulara dikkat ederek akıcı ve anlaşılır bir dille konuşur" şeklinde yer verilmiştir (MEB, 2015). 
Şahbaz ve Çekici (2012), sesbilimin Türkçe eğitimi açısından önemine değinerek sesbilimin, dinleme ve konuşma eğitimi ile bir arada çalışmalar yürütmesinin gerekliliğinden söz etmektedir. İşeri (2002) ise bireylerin konuşma becerisini gerçekleştirebilmesinde parçalı, parçalarüstü sesbirimleri ve sesletim biçimlerini bilmenin önemini vurgulamaktadır. Canbulat, Güven ve Çağlar (2018) Türkçe eğitiminde, dilin en küçük birimi olan seslerin anlaşılır, vurguların doğru ve tonlamaların ise yerinde ve anlamlı olarak verilmesinin gerekliliğinden bahseder.

Türkçe öğretim programı ve ders kitabı biçimbilim bağlamında incelendiğinde programdaki bazı kazanımların ders kitabı etkinliklerine yansımadığı yansımışsa da eksik bir biçimde yansıdığı görülmektedir. Örneğin niteleme ve belirtme sıfatları etkinlik olarak verilmesine rağmen belirtme sıfatları arasında işaret sıfatının verilmemesi konudaki bütünselliği bozmuştur. Programda okuma becerisi başlığı altında "Çekim eklerinin işlevlerini ayırt eder." kazanımına ilişkin "İsim çekim ekleri (çoğul eki, hâl ekleri, iyelik ekleri ve soru eki) üzerinde durulur." açıklaması verilmiştir. Ancak ders kitabında soru ekine ilişkin herhangi bir etkinliğe yer verilmemiştir. Örneğin -DAn ekinin çıkma, ayrılma hali dışında sebep, ilgi, niteleme, karşılaştırma, vasıta, yönelme vb. anlamları da taşımasına rağmen kazanımlarda ve etkinliklerde bu anlamlarına yer verilmediği görülmektedir. Huber (2013), Türkçedeki durum biçimbirimlerinin beş görev ile sınırlandırılmamasına ve bu biçimbirimlerin çeşitli bağlamlarda ortaya çıkan farklı görevlerine de yer verilmesi gerektiğinden söz etmektedir.

Yazınsal ve sözel ifadelerde öğrencilerin duygu ve düşüncelerini etkili bir şekilde anlatabilmelerini, sağlıklı iletişim kurabilmelerini sağlayan en önemli unsurlardan biri olarak gösterebileceğimiz cümle ögesini bilinçli bir şekilde kullanabilmek, sözdizimin doğru ve işlevsel olarak anlaşılmasından geçmektedir. Bu sebeple öğrencilere sözdizimi kazanımlarının ve buna bağlı etkinliklerin aktarılması önemlidir. Buna rağmen araştırma sonucunda programda verilen sözdizimi kazanımları ile ders kitabındaki etkinliklerin diğer alanlara göre yeterli sayıda olmadı̆̆ı gözlemlenmiştir.

Huber'e (2013, s. 280) göre "Bir dili bilmek demek, o dilde metin üretmek ve üretilmiş olan metinleri anlamak demektir. İşte dil öğretmeni de dil derslerini öğrencilerinde bu edinci geliştirmek amacıyla düzenlemelidir." Korkut (2015), öğrencilerin işittiğini ve gördüğünü anlayıp çözümleyerek sözlü ve yazılı iletişim becerilerini geliştirebilmesinde metnin önemine vurgu yapmaktadır. Aşkın Balcı (2018) ise metinlerin dil ve edebiyat eğitimi süreci için vazgeçilmez bir unsur olduğuna dikkat çekmektedir. Türkçe öğretimindeki dört temel beceri alanı ve dilbilgisi, öğrencilere metinler vasıtasıyla aktarılmaktadır. Bu bağlamda temel gayesi bir metni meydana getiren bağıntıları dilbilimsel yöntemler ile çözümlemek ve metnin sistemini ortaya çıkarmak olan metindilbilimin Türkçe eğitimi ile ortaklaşa çalışmalar yapmasının gerekliliği alanyazındaki pek çok araştırmada da (Uçan, 2006; Çıkrıkçı, 2007; Yılmaz ve Topal, 2010; Günay, 2013; Dilidüzgün, 2017; Dilidüzgün ve Genç, 2019) vurgulanmaktadır. Öğretim programı ve ders kitabında bu önem göz önünde bulundurularak yeterli düzeyde metindilbilim etkinliğine yer veriliştir. Programda yer alan metindilbilim kazanımlarının en çok okuma becerisi ile ilişkilendirilerek etkinliklere aktarıldığı görülmüştür. Ayrıca metindilbilim başlığı altında ele alınan kazanımların etkinliklere uyumlu bir şekilde aktarıldığı gözlemlenmiştir.

Öğretim programı ve ders kitabındaki anlambilim/sözcükbilime ilişkin bulgular incelendiğinde büyük bir oranın kelime ve kelime gruplarının öğretimine yönelik olduğu görülmüştür. Kelime ve kelime gruplarının öğretiminde bağlamdan hareket edilmesi gerektiği kazanımlarda belirtilmektedir. Özkan (2010) çalışmasında, bağlam kavramının sözcük öğretimi için hayati öneminden söz etmekte ve bağlamın anlama ulaşmada temel şart olduğunu belirtmektedir. Programda yer alan anlambilim/sözcükbilim kazanımlarının en çok okuma becerisiyle ilişkilendirilerek etkinliklere aktarıldığı görülmüştür. Kaçalin ve Benzer (2006) öğrencilerin ancak bilinçli bir okuma ve anlama ile başarıyı yakalayacaklarını belirterek Türkçe eğitiminde okuma becerisinin ve anlamın önemine dikkat çekmektedir. Türkçe ders kitabında alt anlamlılık, karşıt anlamlılık ve eş anlamlılık kavramları ile ilgili etkinliklere yer verilmesine rağmen Türkçenin anlam özeliklerinden biri olan çokanlamlılığa yer verilmemiştir. Oysa çokanlamlılık, dildeki anlama ve anlatım yönünden önem teşkil etmektedir. Ayrıca Korkut'a göre (2017) dillerde sadece tek anlama sahip olan kelimelerin sayısı oldukça sınırlıdır. Bu nedenlerle öğrencilere sözcüğün değişik anlamlara sahip olabileceğinin de öğretilmesi gerekmektedir. 
Türkçe ders kitabında karşıt anlamlılığa yer verilmiştir ancak etkinlikler, karşıt anlamlılık örneklerinden yön gösteren karşıtıklar ve ikili karşıtıklarla sınırlandırılmıştır. Aksan (2017, s. 103-104) karşıt anlamlılığı; ikili karşıtıklar, biçimsel ilişkili ve ilişkisiz karşıtlıklar, kutupsal karşıtlıklar, ilişkisel karşıtlıklar, dereceli karşıtıklar ve yön gösteren karşıtlıklar olarak sınıflandırmıştır.

Bireylerin karşılıklı etkileşimi ve iletişimini yalnız yazııı ve sözlü kullanımlar değil görüntü, davranış, fotoğraf, resim, harita, grafik, levha, afiş, jest ve mimik, film gibi dil dışı göstergeler de sağlar. Türkçe ders kitaplarında bu tür görsel iletişim ögelerinin de olması önemlidir. Türkçe ders kitabına bakıldığında görsellerin genel kullanımının etkili olduğu görülmüş olup kazanımlarda yer alan "Öğrencilerin haber fotoğrafları ve karikatürleri yorumlayarak görüşlerini bildirmeleri sağlanır." kazanım açıklamasına rağmen ders kitabında haber ya da karikatür okuma ile ilgili herhangi bir etkinliğe yer verilmediği görülmektedir. Yine etkinliklerde görsel okumaya ilişkin; kroki, harita, broşür, slogan ve afiş okumanın yer almasına rağmen programda bu etkinliklere yönelik herhangi bir kazanıma ya da açıklamaya yer verilmediği tespit edilmiştir. Öğretim programı ve ders kitabındaki göstergebilime ilişkin bulgular incelendiğinde en yüksek oranın görselleri yorumlamaya yönelik olduğu görülmüştür. Batur (2010) çalışmasında, görselleri yorumlama becerisi kazanan öğrencilerin kalıcı öğrenmelerle buluşmasının daha kolay gerçekleştiğini belirtmektedir.

Bu sonuçlar doğrultusunda, parçalar üstü sesbirimlerden olan ve anlam ayırt eden vurgu, tonlama yanında uzunluk, ezgi, hız, ritim, durak gibi sesbirimler de kazanımlara ve etkinliklere yansıtılıp öğretilebilir. Bir başka deyişle öğretim programları ve ders kitaplarında sesbilime yönelik kazanım ve etkinlikler arttırılabilir. Biçimbilim ve sözdizimi alanında verilen etkinliklerde dilbilimin ilke ve yöntemleri temel ölçü olmalıdır. Bu bağlamda Türkçe ders kitaplarında dilbilgisi beceri alanı altında verilen biçimbilim ve sözdizimi etkinlikleri yeniden gözden geçirilmeli gerekirse dilbilimin ilkeleri bağlamında yeniden hazırlanmalı, öğrenciler kuralcı, kategorize edilmiş, ezber dilbilgisi yerine işlevsel dilbilgisi öğretimiyle buluşturulmalıdır. Ayrıca biçimbilim ve sözdizimi etkinliklerinde öğrencilerin algılamalarını hızlandırmak için görsel ögelere ağırlık verilerek somutlaştırmalar yapılabilir. Göstergebilime ilişkin kazanımlarda ve etkinliklerde grafik, tablo, karikatür, fotoğraf, harita, resim vb. dil dışı göstergeleri okumaya daha fazla yer verilerek öğrencilerin çözümleme, çıkarımda bulunma, eleştirel ve yansıtıcı düşünme, akıl yürütme ve görsel okuma gibi becerilerinin gelişimine katkılar sunulabilir.

\section{Yazarların Katkı Oranı}

Birinci yazar araştırma fikrinin ortaya çıkması, literatür taraması, araştırma verilerinin toplanması ve incelenmesi ile araştırmanın raporlanması aşamalarında, ikinci yazar araştırma fikrinin geliştirilmesi, yöntemin belirlenmesi, tartışma bölümünün zenginleştirilmesi ve makalenin genel düzenlemesinde katkıda bulunmuştur.

\section{Çıkar Çatışması}

Araştırmada çıkar çatışması teşkil edebilecek bir durum bulunmamaktadır.

\section{Kaynaklar}

Aksan, D. (2004). Dilbilim ve Türkçe yazıları. Multilingual Yayınları.

Aksan, D. (2017). Anlambilim (Anlambilim konuları ve Türkçenin anlambilimi). Bilgi Yayınevi.

Alyaz, Y. (2006). Dilbilim dersinin içerik, amaç ve kazanımlarına yönelik öğrenci tutumları. Uludağ Üniversitesi Eğitim Fakültesi Dergisi, 19(1), 23-44.

Aşkın Balcı, H. (2018). Metindilbilimin ABC'si. Say Yayınları.

Aydın, Ö. (1999). Ortaokullarda dilbilgisi öğretimi üzerine öğretmen görüşleri. Dil Dergisi, 81, 23-29.

Batur, Z. (2010). Ana dili öğretiminde gösterge biliminin yeri: ana dili ders kitaplarındaki sözel metinlerle görsel metinleri bütünselliğinin analizi. Turkish Studies, 5(4), 174-200.

Börekçi, M. (1997). Türk dilinin en büyük sorunlarından biri: Dilbilimin dil öğretimine yansımamış olması. Tömer Dil Dergisi, 56, 12-17. 
Börekçi, M. (2009). Türk dili edebiyatı ve Türkçe öğretmenlerinin yetiştirilmesi sürecinde dilbilim ve Türkçe öğretimi. Turkish Studies, 4(3), 419-429.

Canbulat, M., Çağlar, M. Ç. ve Güven, Ö. (2018, Mayıs). Türkçe öğretmenliği lisans programlarında dilbilimin yeri. 32. Ulusal Dilbilim Kurultayı, İzmir, Türkiye.

Canbulat, M., Güven, Ö. ve Çağlar, M. Ç. (2018, Mayıs). Türkçe eğitiminde diksiyon ve etkili konuşma becerisinin öğretimi üzerine bir inceleme. International EJER Congress, Antalya, Türkiye.

Çağlayan Dilber, N. (2017). Dilbilim kavramları ışığında Türkçe öğretimi. International Journal of Languages Education and Teaching, 5(4), 777-786.

Çıkrıkçı, S. S. (2007). Metindilbilimin temel kavramlarının anadili öğretim süreci açısından değerlendirilmesi. Dil Dergisi, 138, 43-57.

Dilidüzgün, Ş. (2017). Metindilbilim ve Türkçe öğretimi uygulamalı bir yaklaşım. (1. baskı). Anı Yayıncilık.

Dilidüzgün, Ş. ve Genç, Ş. (2019). Türkçe dersi okuma kazanımlarının metin yapı ölçütlerini karşılama yeterliği: 8. sınıf örneği. Uluslararası Sosyal Araştırmalar Dergisi, 12(64), 562-571.

Enginarlar, H. (2006). Dilbilim ve dil öğretimi. A. Kocaman (Yay. Haz.), Dilbilim temel kavramlar, sorunlar, tartışmalar (s. 151-160). Dil Derneği Yayınları.

Günay, D. (2013). Metin bilgisi. Papatya Yayıncılık.

Güneyli, A. ve Küçükavşar, A. (2008, Mayıs). Anadili eğitiminde dilbilimin yan alanlarından yararlanma. International Symposium on Social Sciences Education, Çanakkale, Türkiye.

Güneyli, A. ve Küçükavşar, A. (2011, Eylül). Türkçe öğretmeni adaylarının dilbilim ve dilbilgisi kavramlarına ilişkin algıları. 4. Uluslararası Türkçenin Eğitimi-Öğretimi Kurultayı, Sakarya, Türkiye.

Huber, E. (2013). Dilbilime giriş. Multilingual Yayınları.

İmer, K. (1990). Dilbilim ve anadili öğretimi. Çağdaş Türk Dili Dergisi, 30-31, 874-878.

İmer, K. ,Kocaman, A. ve Özsoy, A. S. (2019). Dilbilim sözlüğü. Boğaziçi Üniversitesi Yayınevi.

İşeri, K. (2002). Türkçe ders kitaplarındaki metinlerin ilköğretim programına uygunluğunun incelenmesi: göstergebilimsel bir betimleme (Doktora Tezi). Ankara Üniversitesi, Sosyal Bilimler Enstitüsü.

Kaçalin, M. S. ve Benzer, A. (2006). Müfredat programlarında okuma eğitimi. C. Yıldız ve L. Beyreli (Editörler), Edebiyat, edebiyat öğretimi ve deyişbilim yazıları cilt 2 (s. 420-428). Pegem A Yayınları.

Kıran, Z. ve Kıran, A. E. (2013). Dilbilime giriş (4. baskı). Seçkin Yayınları.

Kocaman, A. (1998). Söylem çalışmaları ve Türkçe öğretimi. K. İmer ve L. S. Uzun (Yay. Haz.), Doğan Aksan armağanı (s. 101-106). Ankara Üniversitesi Dil, Tarih-Coğrafya Fakültesi Yayınları.

Kocaman, A. (2006). Uygulamalı dilbilim. A. Kocaman (Yay. Haz.), Dilbilim temel kavramlar, sorunlar, tartışmalar (s. 161-166). Dil Derneği Yayınları.

Kocaman, A. (2009a). Dil ve eğitimi düşünmek. Toroslu Kitaplığı.

Kocaman, A. (2009b). Dilbilim ve Türkçe incelemeleri. International Journal of Central Asian Studies, 13, 365-371.

Korkut, E. (2015). Metin dilbilim ve dil öğretimi. E. Korkut ve í. Onursal Ayırır. (Editörler), Dil bilimleri ve dil öğretimi (s. 159-188). Seçkin Yayınevi.

Korkut, E. (2017). Söz ve kimlik: söylemler bize ne söyler? Seçkin Yayınevi.

MEB. (2015). Türkçe Dersi (1-8. Sınıflar) Öğretim Programı. Millî Eğitim Bakanlığı Yayınları.

Özkan, B. (2010, Temmuz). Ana dili olarak Türkçenin öğretiminde dinleme/izleme etkinlikleri üzerine bir değerlendirme. III. Uluslararası Türkçenin Eğitimi-Öğretimi Sempozyumu, İzmir, Türkiye.

Sezer, A. (1988). Türkçe öğretiminde dilbilimin yeri. Türk Dilinin Öğretimi Toplantısı (s. 43- 51). Ankara Üniversitesi Eğitim Bilimleri Fakültesi Yayınları:160.

Şahbaz, N. K. ve Çekici, Y. E. (2012). Disiplinler arası bir disiplin olarak Türkçe eğitimi. Turkish Studies, $7(3), 2367-2382$.

Tura, S. S. (1983). Dilbilimin dil öğretimindeki yeri. Türk Dili Dil ve Edebiyat Dergisi (Dil Öğretimi Özel SayısI), 47(379-380), 8-17.

Uçan, H. (2006). Yazınsal eleştiri ve göstergebilim. Hece Yayınları. 
Yıldırım, A. ve Şimşek, H. (2018). Sosyal bilimlerde nitel araştırma yöntemleri. Seçkin Yayıncılık.

Yılmaz, E. ve Topal, Z. (2010). Türkçe öğretiminde metindilbilimsel yöntemin uygulanması. Türklük Bilimi Araştırmaları Dergisi, 27, 775-788.

\section{Introduction}

\section{Extended Abstract}

All people acquire the language of the society in which they live. Language education is an important component of general education. Language education aims to develop language skills of individuals and equips them with effective communication skills, and it generally refers to mother tongue education.

Mother tongue education is given in Turkish classes. Accordingly, the primary objectives of Turkish education are to give individuals the opportunity to learn their mother tongue and to understand its system and functioning. To achieve those objectives, it is important to prepare a curriculum, course components and materials, based on the teaching of four basic language skills and grammar on a sound scientific basis. The discipline that provides a wealth of resources for the realization of those objectives is undoubtedly linguistics and its subfields.

Linguistics is the scientific study of language. The most radical contribution of linguistics to language teaching is the scientific perspective it offers. This point of view has brought a qualified, functional and objective dimension to language studies and language teaching.

The use of linguistic insights in language teaching is not reflected the teaching of Turkish (Kocaman, 2006; Alyaz, 2006; Börekçi, 2009; Kıran and Kıran, 2013). Kocaman (2009a) states that in the teaching of Turkish, linguistics is not even mentioned. Sezer (1988) reports the same finding two decades earlier and says that the inclusion of linguistics in Turkish education is almost non-existent. According to Börekçi (1997), one of the biggest problems in Turkish teaching is that linguistic insights are not reflected in language teaching. Research by Tura (1983), Imer (1990), Aydın (1999), Kocaman (1998, 2009b), Aksan (2004), Enginarlar (2006), Güneyli and Küçükavşar (2008, 2011), Çağlayan Dilber (2017), and Canbulat, Çağlar and Güven (2018) confirm these views.

This study aimed to examine the learning outcomes for the $6^{\text {th }}$ grade in the 2018 Turkish curriculum and the activities in the corresponding Turkish course book from the standpoint of linguistics. Accordingly, in the examination of the learning outcomes and activities, the following branches of linguistics formed the linguistic criteria:

a) Phonology

b) Morphology and syntax

c) Text linguistics

d) Semantics and lexicology

e) Semiotics

\section{Method}

The sample in this study, which was carried out in the qualitative research paradigm, consisted of the $6^{\text {th }}$ grade Turkish Curriculum of 2018 and the regular middle school and religious middle school Turkish course book published by the MEB Publications in the same year. Content analysis was used in data analysis.

\section{Result and Discussion}

The results showed that the Turkish curriculum and the course book were largely compatible, and the linguistic concepts listed in the learning outcomes of the curriculum were reflected in the activities. In the curriculum and the course book, it was seen that the majority of the gains were related to text linguistics and the areas in which gains were seen the least were phonetics and syntax. Regarding phonetics, it was observed that stress and intonation were not included in the curriculum although they were included in the activities. In addition, only some of the morphology related learning outcomes were reflected in the course book activities. 
The four skills and grammar were taught through texts. There was sufficient amount of activities in this regard. Text linguistics related learning outcomes in the curriculum and the textbook were mostly associated with reading skills. When the findings related to semantics/lexicology were analyzed, it was seen that a large proportion of the activities was about the teaching of words and word groups.

When the findings related to semiotics were analyzed, it was seen that there was not any activity related to reading news or caricatures in the textbook. It was also seen that interpreting images was mostly used.

In line with these results, the learning outcomes and the number of activities for phonetics may be increased in the curriculum and the course book. Principles and methods of linguistics should be the primary criteria in the revision of the morphology and syntax activities in the course book, and active participation of students in the teaching of grammar should be included instead of teacher-led grammar instruction. 